\title{
Assessment of Anti-Nutrient and Vitamin Compositions of Pleurotus Ostreatus Cultivated on three Waste Materials
}

\author{
AGBAGWA, S. S., CHUKU, E. C. \& WEKHE, O. \\ Lecturer, Department of Plant Science and Biotechnology, \\ Rivers State University, Rivers State, Nigeria
}

\begin{abstract}
Studies on the assessment of anti-nutrient and vitamin compositions of Pleurotus ostreatus cultivated on three agrowastes materials were carried out in Dilomat Farms and Services Limited and Department of Plant Science and Biotechnology, Rivers State University. Ten treatments were obtained from the mixtures of cassava bran, wood ash and sawdust at different concentrations which also comprised the control and combined effect. Vitamins assessed were Vitamins A, C, Thiamine and Niacin. The combined effect (CE) had the highest contents of these vitamins investigated. However, minimal concentrations of Vitamin $C$ was recorded. Anti-nutrient analysis showed that the CE treatment had highest values of phytate (1.95 \pm 0.00$)$, oxalate

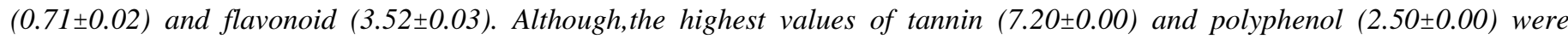
recorded for sawdust and cassava bran (SCB) treatment. The Highest concentration of saponin (0.08 \pm 0.00$)$ was observed for sawdust and wood ash (SWA) treatment than others. Nevertheless, there was no fruit recorded for higher concentrations of SCB treatment due to contamination. The cyanide concentrations $(0.03 \pm 0.02$ to $0.52 \pm 0.01)$ for treatments containing cassava bran were all within the acceptable limit. Generally, the combined effect treatment performed better than every other treatment utilized.
\end{abstract}

Key Words: Anti-nutrient, Vitamin, Waste Material, Pleurotus Ostreatus.

\section{INTRODUCTION}

Mushrooms popularly recognized by their fruiting bodies grow naturally in the wild, although they are currently cultivated by man for different purposes. Literature has shown that mushroom domestication was firstly recorded in China (Chang \& Miles, 1989). Ascomycetes and basidiomycetes under the Ascomycota and Basidiomycota divisions respectively are the taxons where mushrooms have been classified; most of which are either consumed or utilized because of their medical and environmental importance (Fasidi et al., 2008). In addition, some mushrooms have been implicated by early researchers to be poisonous when consumed and could also portray some alellopathic property (Chuku \& Nwobiowhuru, 2009).

Literature has shown that Pleurotus genus possesses several nutritional components including proximate, mineral, amino acids, vitamins and phytochemicals (Islam et al., 2017). Chirinang \& Intarapichet, (2009) implicated the presence of several amino acids such as alanine, arginine, glycine, leucine, tyrosine and many more in Pleurotus ostraetus and P. sajor-caju. Phytochemicals such as alkaloids, flavonoids, phenol, tannin and saponin have also been reportedly found in Pleurotus (Nwoko et al., 2017; Wekesa et al., 2016). Vitamins including renitol (A), thiamine (B1), niacin (B3), riboflavin (B2) and ascorbic acid (C) were all associated with oyster mushroom (Nwoko et al., 2018).

Quite a number of works have shown the medicinal potential of anti-nutrients in oyster mushroom. According to the research of Akyuz et al., (2010) mushroom possessed antimicrobial property as it was able to inhibit bacterial and fungal organisms. Antimutagenic property of Pleurotus genus was also indicated by Filipic et al., (2002). Oyster mushrooms have also been reported to have antioxidant, hyperglycemic, anti-lipidemic and anti-inflammatory properties (Patel et al., 2012; Chakravarty, 2011).

There is scanty literature on anti-nutrient and vitamin compositions of $P$. ostreatus grown on sawdust, wood ash and cassava bran. It is on this basis this research was carried out to assess these contents. 


\section{MATERIALS AND METHODS}

\subsection{Sample Collection}

Sawdust and Rhizophora racemosa wood were both obtained from Timber market Mile II Diobu. R. racemosa woods were later burnt to collect the ash. Cassava peels were collected from Omagwa community in Ikwerre Local Government Area, Rivers state. The peels were dried for one month and immediately ground into powder for further use. Healthy spawns of Pleurotus ostreatus were bought from Dilomat Farms and Services Limited, Rivers State University for the study. The above materials were all conveyed to the experimental site at Dilomat farms.

\subsection{Substrate compositions}

The materials used for the cultivation were cassava bran, wood ash and sawdust and were subjected to various mixtures leading to their respective compositions for the experiment. Three concentrations of cassava bran (100, 150 and $200 \mathrm{~g})$ and wood ash (0.30, 0.60 and $1.0 \mathrm{~g})$ were varied against a constant quantity of sawdust $(1000 \mathrm{~g})$. Combined and control treatments were also set up. A total of ten treatments were used for the cultivation of P. ostreatus:

Sawdust and wood ash (SWA): SWA1, SWA2, SWA3

Sawdust and cassava bran (SCB): SCB1, SCB2, SCB3

Combined effect (CE): CE1, CE2, CE3

Control (C)

The numbers attached to the abbreviated formulation indicate the concentration levels of wood ash and cassava bran in an increasing order.

\subsection{Cultivation Studies}

The cultivation methods of Chinda \& Chinda, (2009) were adopted for this research. The different substrate compositions were composted for 40days. At the end of composting, the substrates were immediately bagged and sterilized through pasteurization at $100^{\circ} \mathrm{C}$ for 6hours. After the sterilized bags cooled, they were inoculated with $74.99 \pm 21.66 \mathrm{~g}$ of spawn and incubated at room temperature $\left(25 \pm 3^{0} \mathrm{C}\right)$ for 38 days. Fully colonized bags were immediately cropped and watered for 3 days. Fruiting bodies were later harvested and subjected to various studies.

\subsection{Nutrient Composition Studies}

The determination of Vitamins and anti-nutrients contents of harvested P. ostreatus mushroom from the various substrate composition were done using the methods earlier described by AOAC, (2005); (1990). Data obtained were all subjected to SPSS statistical analysis. 
International Journal of Research in Agriculture, Biology \& Environment (ijagri), Vol. 1(2), Jul-Sep-2020

\section{RESULTS}

Table 1: Effect of different substrate compositions on the anti-nutrient composition of P. ostreatus (\%)

\begin{tabular}{|c|c|c|c|c|c|c|c|}
\hline $\begin{array}{l}\text { Sub. } \\
\text { Comp. }\end{array}$ & Phytate & Oxalate & Tannin & Polyphenol & Flavonoid & Saponin & $\begin{array}{l}\text { Cyanide } \\
(\mathrm{mg} / 100 \mathrm{~g})\end{array}$ \\
\hline $\mathbf{C}$ & $0.14 \pm 0.01^{\mathrm{a}}$ & $0.20 \pm 0.00^{b}$ & $0.17 \pm 0.00^{\mathrm{ab}}$ & $1.57 \pm 0.00^{\mathrm{a}}$ & $2.12 \pm 0.00^{\mathrm{a}}$ & $0.05 \pm 0.00^{b c}$ & - \\
\hline CE1 & $1.94 \pm 0.00^{\mathrm{e}}$ & $0.65 \pm 0.00^{f}$ & $1.02 \pm 0.00^{\mathrm{d}}$ & $1.87 \pm 0.00^{f}$ & $3.52 \pm 0.03^{g}$ & $0.05 \pm 0.00^{b}$ & $0.03 \pm 0.02^{\mathrm{a}}$ \\
\hline CE2 & $1.41 \pm 0.01^{\mathrm{d}}$ & $0.55 \pm 0.00^{\mathrm{e}}$ & $0.92 \pm 0.01^{\mathrm{c}}$ & $1.72 \pm 0.00^{\mathrm{d}}$ & $3.20 \pm 0.00^{\mathrm{d}}$ & $0.02 \pm 0.00^{\mathrm{a}}$ & $0.52 \pm 0.01^{b}$ \\
\hline CE3 & $1.95 \pm 0.00^{\mathrm{e}}$ & $0.71 \pm 0.02^{g}$ & $5.02 \pm 0.02^{\mathrm{e}}$ & $1.91 \pm 0.01^{\mathrm{g}}$ & $3.42 \pm 0.02^{f}$ & $0.06 \pm 0.01^{b c}$ & $0.05 \pm 0.01^{\mathrm{a}}$ \\
\hline SCB1 & $0.94 \pm 0.00^{c}$ & $0.00 \pm 0.00^{\mathrm{a}}$ & $7.20 \pm 0.00^{f}$ & $2.50 \pm 0.00^{\mathrm{h}}$ & $3.34 \pm 0.00^{\mathrm{e}}$ & $0.05 \pm 0.00^{b}$ & $0.05 \pm 0.00^{\mathrm{a}}$ \\
\hline SCB2 & - & - & - & - & - & - & - \\
\hline SCB3 & - & - & - & - & - & - & - \\
\hline SWA1 & $0.14 \pm 0.00^{\mathrm{a}}$ & $0.22 \pm 0.00^{b}$ & $0.18 \pm 0.00^{b}$ & $1.59 \pm 0.00^{b}$ & $2.15 \pm 0.01^{\mathrm{ab}}$ & $0.06 \pm 0.00^{b c}$ & - \\
\hline SWA2 & $0.18 \pm 0.00^{b}$ & $0.34 \pm 0.01^{\mathrm{c}}$ & $0.16 \pm 0.00^{\mathrm{a}}$ & $1.61 \pm 0.00^{c}$ & $2.17 \pm 0.01^{b}$ & $0.06 \pm 0.00^{c}$ & - \\
\hline SWA3 & $0.18 \pm 0.00^{b}$ & $0.51 \pm 0.00^{d}$ & $0.18 \pm 0.00^{\mathrm{ab}}$ & $1.83 \pm 0.00^{\mathrm{e}}$ & $3.00 \pm 0.00^{c}$ & $0.08 \pm 0.00^{\mathrm{d}}$ & - \\
\hline
\end{tabular}

*Means with the same superscript across the column are not significantly different $(\mathrm{p} \leq 0.05)$

- = no harvest and Sub. Comp.=Substrate composition 
International Journal of Research in Agriculture, Biology \& Environment (ijagri), Vol. 1(2), Jul-Sep-2020

Table 2: Effect of different substrate compositions on the vitamin composition of $P$. ostreatus $(\mathrm{mg} / 100 \mathrm{~g})$

\begin{tabular}{|c|c|c|c|c|}
\hline Sub. Comp. & Vitamin C & Vitamin A & Thiamin & Niacin \\
\hline $\mathrm{C}$ & $0.00 \pm 0.00^{\mathrm{a}}$ & $0.52 \pm 0.02^{b}$ & $0.65 \pm 0.00^{b}$ & $0.12 \pm 0.00^{b}$ \\
\hline CE1 & $0.00 \pm 0.00^{\mathrm{a}}$ & $5.12 \pm 0.02^{f}$ & $2.10 \pm 0.00^{f}$ & $1.43 \pm 0.04^{\mathrm{d}}$ \\
\hline CE2 & $0.01 \pm 0.00^{b}$ & $0.62 \pm 0.01^{\mathrm{c}}$ & $1.21 \pm 0.01^{\mathrm{d}}$ & $1.81 \pm 0.01^{f}$ \\
\hline CE3 & $0.00 \pm 0.00^{\mathrm{a}}$ & $5.00 \pm 0.00^{\mathrm{e}}$ & $2.30 \pm 0.14^{g}$ & $1.53 \pm 0.04^{\mathrm{e}}$ \\
\hline SCB1 & $0.00 \pm 0.00^{\mathrm{a}}$ & $0.00 \pm 0.00^{\mathrm{a}}$ & $0.00 \pm 0.00^{\mathrm{a}}$ & $0.00 \pm 0.00^{\mathrm{a}}$ \\
\hline SCB2 & - & - & - & - \\
\hline SCB3 & - & - & - & - \\
\hline SWA1 & $0.00 \pm 0.00^{\mathrm{a}}$ & $0.51 \pm 0.02^{b}$ & $0.65 \pm 0.00^{b}$ & $0.13 \pm 0.00^{b}$ \\
\hline SWA2 & $0.00 \pm 0.00^{\mathrm{a}}$ & $0.62 \pm 0.02^{c}$ & $1.77 \pm 0.00^{\mathrm{e}}$ & $0.16 \pm 0.01^{b}$ \\
\hline SWA3 & $0.01 \pm 0.00^{b}$ & $0.81 \pm 0.01^{\mathrm{d}}$ & $0.85 \pm 0.00^{c}$ & $0.21 \pm 0.02^{c}$ \\
\hline
\end{tabular}

*Means with the same superscript across the column are not significantly different $(\mathrm{p} \leq 0.05)$

- = no harvest and Sub. Comp.=Substrate compositions

The result of effect of different substrate compositions on the anti-nutrient composition of cultivated $P$. ostreatus presented in Table 1 indicated the presence of phytate, oxalate, tannin, polyphenol, flavonoid, saponin and cyanide. Treatment CE3 recorded highest values for phytate $(1.95 \pm 0.00)$ and oxalate $(0.71 \pm 0.02)$ while tannin $(7.20 \pm 0.00)$ and polyphenol $(2.50 \pm 0.00)$ were highest in treatment SCB1. However, flavonoid, saponin and cyanide were found to be highest in CE1 (3.52 \pm 0.03$)$, SWA3 $(0.08 \pm 0.00)$ and CE2 (0.52 \pm 0.01$)$ respectively. On the other hand, lowest values $(0.18 \pm 0.00,0.00 \pm 0.00,0.16 \pm 0.00,1.57 \pm 0.00,2.12 \pm 0.00,0.02 \pm 0.00$ and $0.03 \pm 0.02)$ were recorded for C and SWA1, SCB1, SWA2, C, C, CE2 and CE1 respectively. Treatments SCB2 and SCB3 did not record any harvest due to microbial contamination.

The result of different substrate compositions effect on the vitamin composition of $P$. ostreatus presented in Table 2, revealed the presence of vitamins C, A, thiamin and niacin. Although, vitamin C recorded $0.01 \pm 0.00$ for both CE2 and SWA3, every other treatment was $0.00 \pm 0.00$. The data for the remaining vitamins assessed showed that highest values $(5.12 \pm 0.02,2.10 \pm 0.00$ and $1.81 \pm 0.01$ ) were obtained for CE1, CE2 and CE2 for vitamins A, thiamin and niacin respectively. SCB1 had the lowest values $(0.00 \pm 0.00)$ for vitamins A, thiamin and niacin. No result was obtained for SCB2 and SCB3 in this study.

\section{DISCUSSION}

The result for anti-nutrient composition of $P$. ostreatus tested by ANOVA revealed that there was significant difference on the effect of different substrate compositions on the anti-nutrient composition of cultivated $P$. ostreatus at $\mathrm{p} \leq 0.05$. Generally, samples from the combined treatment (CE) performed better than other tested treatments. The cyanide content of the harvested P. ostreatus in this study 


\section{International Journal of Research in Agriculture, Biology \& Environment (ijagri), Vol. 1(2), Jul-Sep-2020}

agrees with the guide line of FAO/WHO, (1991) as they recommended less than $10 \mathrm{mg} / \mathrm{kg}$. Hence the oyster mushroom cultivated in this study is fit for consumption.

Several researches have shown and implicated Pleurotus species including P. ostreatus to possess different kinds of anti-nutrients (Adebayo \& Oloke, 2017). Duru et al., (2019) showed the occurrence of saponin, alkaloid, oxalate, tannin, phytate and flavonoid in P.ostreatus and the values they reported were similar to those recorded in this study. P. pulmonarius was also reported by Nwoko et al., (2017) to contain the same anti-nutrients as recorded in this study. Oyekanmi et al., (2019) further confirmed the occurrence of these anti-nutrients in $P$. ostreatus, although they further showed that these anti-nutrients conferred anti-microbial properties to $P$. ostreatus as they aided the inhibition of several bacteria.

Furthermore, the medical importance of these anti-nutrients in Pleurotus species have been exploited by early researchers as they revealed not just the ability to inhibit microbes; but also their capabilities as antioxidant, anti-viral, ant-lipidemic and antimutagenic (Patel et al., 2012; Selegean et al., 2009; Lakshmi et al., 2014).

The current study has shown that there is a significant difference in the effect of different substrate compositions on the vitamin composition of $P$. ostreatus at $\mathrm{p} \leq 0.05$. The combined effect (CE) contained more vitamins than other treatments generally and there was very little amount of vitamin $\mathrm{C}$ recorded across the treatments investigated.

Iqbal et al., (2016) reported higher value of vitamin C $(11.11 \mathrm{mg} / 100 \mathrm{~g})$ for $P$. florida than those in this study. The vitamin results in this study are higher than those reported by Duru et al., (2019) for $P$. ostreatus with an exception for vitamin C only. Nevertheless, the mineral results of the present study disagree with the findings of Nwoko et al., (2018) for P. pulmonarius as they reported higher values of vitamins A, C and niacin. But a lower value of thiamin was also reported. Okwulehie \& Nosike, (2015) reported lower value for niacin for $P$. pulmonarius compared to that recorded in this study, although, higher values of vitamin $\mathrm{C}$ was also reported.

Vitamins are vital and essential for healthy living as they contribute to proper vision (vitamin A), balanced immune system (vitamin C) and prevention of some illness like beriberi (thiamine B1) (Nwoko et al., 2018; Piska et al., 2017).

\section{CONCLUSION}

Cassava bran, wood ash and sawdust waste materials utilized in the present study played a crucial role in the anti-nutrient and vitamin compositions of the harvested $P$. ostreatus. However, the combined effect performed better than every other treatment and the cyanide concentrations are within the acceptable limit.

\section{REFRENCES}

Adebayo, E. A., \& Oloke, J. K. (2017). Oyster mushroom (Pleurotus species): A natural functional food. J. of Microbiol. Biotechnol \& Food Sci., 7(3): 254-264.

Akyuz, M., Onganer, A. N., Erecevit, P., \& Kirbag, S. (2010). Antimicrobial activity of some edible mushrooms in the eastern and southeast Anatolia region of Turkey. G. U. J. Sci., 23(2): 125-130.

AOAC, (1990). Official methods of analysis of AOAC international. $15^{\text {th }}$ edition. Association of official analytical chemists, Washington, D.C., USA.

AOAC, (2005). Official methods of analysis of AOAC international. $18^{\text {th }}$ edition. Association of official analytical chemists, Washington, D.C., USA.

Chakravarty, B. (2011). Trends in mushroom cultivation and breeding. Australian J. of Agric. Engineering, 2(4): 102-109.

Chang, S. T., \& Miles, P. G. (1989). Edible mushrooms and their cultivation. Chinese University of Honk $\backslash g$ Kong.

Chinda, M. M., \& Chinda, F. (2007). Mushroom cultivation for health and wealth. Image and Media Associates Ltd., pp104.

Chirinang, P., \& Intarapichet, K. (2009). Amino acids and antioxidant properties of the oyster mushrooms, Pleurotus ostreatus and $P$. sajor-caju. Science Asia, 35: 326-331. 


\section{International Journal of Research in Agriculture, Biology \& Environment (ijagri), Vol. 1(2), Jul-Sep-2020}

Chuku, E. C., \& Nwobiowhuru, I. S. (2009). Preliminary studies on some poisonous mushroom in Rivers State. Nigerian J. of Mycol., 2(3): 222-228.

Duru, M., Eboagwu, I., Kalu, W., \& Odika, P. (2019). Nutritional, anti-nutritional and biochemical studies on the oyster mushroom, Pleurotus ostreatus. E. C. Nutrition, 14(1): 36-59.

FAO/WHO, (1991). Joint FAO/WHO food standards programs. In:Codex Alimentarius Commision xii (suppl. 4) Rome, Italy: FAO.

Fasidi, I. O., Kadiri, M., Jonathan, S. G., Adenipekun, C. O., \& Kuforiji, O. O. (2008). Cultivtaion of edible tropical mushrooms. Ibadan University Press, pp77.

Filipic, M., Umek, A., \& Minaric, A. (2000). Screening of basidiomycetes mushroom extracts for antigluotix and bioantimutagenic activity. Pharmazie, 57: 4116-4120.

Iqbal, B., Khan, H., Khan, I., Shan, B., Naeem, A., Ullah, W., Khan, N., Adnan, M., Shah, S. R. A., Junaid, K., Ahmed, N., \& Iqbal, M. (2016). Substrates evaluation for the quality, production and growth of oyster mushroom (Pleurotus florida Cetto). J. of Entomology and Zoology Studies, 4(3): 98-107.

Islam, T., Zakaria, Z., Hamidin, N., \& Ishak, M. A. (2017). Analysis of major nutritional components of Pleurotus pulmonarius during cultivation in different indoor environmental conditions on sawdust. Turkish J. of Agric. Food Sci. \& Technol., 5(3): 239-246.

Lakshmi, B., Jose, N., Ajith, T. A., \& Jananrdhanan, K. K. (2014). Antimutagenic activity of methanolic extract of culinary-medicinal oyster mushroom, Pleurotus ostreatus (Jacq:Fr.) Kumm. (strain floric Eger nom. Nud.) and its protective effect against bennzo (a) pyrene-induced hepatic damages. Int. J. Med. Mush., 6:139-149.

Nwoko, M. C., Achufusi, J. N., Ahaiwe, M. C., \& Ehumadu, C. R. (2018). Evaluation of yield, heavy metals and vitamins compositions of Pleurotus pulmonarius (Freis) Quell fruit bodies cultivated on three deciduous tree logs. J. of Environ. Sci. \& Pub. Health, 2(4): 210-220.

Nwoko, M. C., Onyeizu, U. R., Okwulehie, I. C., \& Ukoima, H. N. (2017). Nutritional and bioactive compounds evaluation of Pleurotus pulmonarius (Freis) quell fruit bodies grown on different wood logs in Abia state, Nigeria. J. Pet. Environ. Biotechnol., 7: 325.

Okwulehie, I. C., \& Nosike, E. N. (2015). Phytochemicals and vitamin compositions of Pleurotus pulmonarius cultivated on barks of some indigenous fruit tress supplement with agro-wastes. Asian J. of Plant. Sci. \& Res., 5(2): 1-7.

Oyekanmi, B. A., Onifade, A. K., Osho, I. B., \& Adetuyi, F. C. (2011). Assessment of antimicrobial properties and bioactive agents inherent in P. ostreatus. Niger J. Mycol., 11:129-144.

Patel, Y., Naraian, R., \& Singh, V. K. (2012). Medicinal properties of Pleurotus species (Oyster mushroom): A review. World J. of Fungal \& Plant Biol., 3(1): 1-12.

Piska, K., Sulkowska-Ziaja, K., \& Muszynska, B. (2007). Edible mushroom Pleurotus ostreatus (Oyster mushroom)- its dietary significance and biological activity. Acta Sci. Pol. Hortorum Cultus, 16(1): 151-161.

Selegean, M., Putz, M. V., \& Rugea, T. (2009). Effect of the polysaccharide extract from the edible mushroom Pleurotus ostreatus against infectious Bursal Disease Virus. Int. J. Mol. Sci., 10:3616-3634.

Wekesa, N. J., Lilechi, D. B., Sigot, A., Cheruiyot, J. K., Kamau, R. W., \& Kisiangani, P. (2006). Volatile and non-polar chemical constituents of cultivated oyster mushroom Pleurotus ostreatus. Int. J. of Pharmacognosy \& Phuytochemical Res., 8(3): 477479 . 